\title{
Odległa obserwacja wyników badania SMILE-4 - nowe dane na temat korzyści z przyjmowania zofenoprilu
}

\author{
Prof. dr hab. n. med. Krzysztof J. Filipiak, FESC \\ I Katedra i Klinika Kardiologii, Warszawski Uniwersytet Medyczny, Warszawa
}

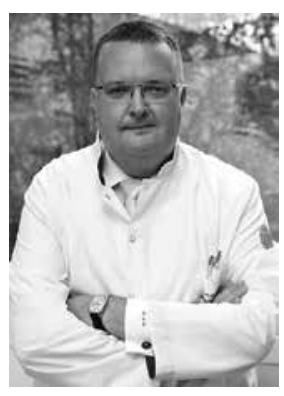

WSTĘP

Druga dekada XXI wieku w historii inhibitorów konwertazy angiotensyny (ACE) zapisze się, moim zdaniem, jako okres powrotu do inhibitorów ACE z grupą sulfhydrylową w budowie. O ile zainteresowanie kaptoprilem jest czysto teoretyczne (lek podawany 3 razy dziennie, praktycznie bez znaczenia we współczesnych schematach leczenia hipotensyjnego), o tyle drugi lek o takiej budowie — zofenopril, nowoczesny, lipofilny inhibitor ACE przeznaczony do podawania raz na dobę, wzbudza coraz większe zainteresowanie. Niewątpliwie powodów tego zainteresowania jest kilka. Za najważniejsze dwa uważam:

- licznie publikowane wyniki obserwacji wskazujące na to, że podawanie zofenoprilu wiąże się ze zwiększeniem biodostępności siarkowodoru $\left(\mathrm{H}_{2} \mathrm{~S}\right)$ - prawdopodobnie w mechanizmie pobudzania reakcji tworzenia $\mathrm{H}_{2} \mathrm{~S}$ przez reszty sulfhydrylowe zawarte w tej cząsteczce;

- opublikowanie w 2012 roku wyników przełomowego badania typu head-to-head (bezpośrednie, prospektywne, prowadzone metodą podwójnie ślepej próby porównanie dwóch leków, bez grupy przyjmującej placebo) SMILE-4 (Survival of Myocardial Infarction Long-term Evaluation 4), oraz, omawianej w komentarzu, opublikowanej w 2017 roku obserwacji odległej tego badania. Spróbujmy zatem jeszcze raz przyjrzeć się obu tym ważnym argumentom.

\section{CZEMU SŁUŻĄ ZWIĘKSZONE STĘŻENIA H $\mathrm{H}_{2} \mathrm{~S}$ ? CZEMU SŁUŻĄ LEKI GENERUJĄCE PRODUKCJE $\mathrm{H}_{2} \mathrm{~S}$ ?}

Obecnie w fizjologii naczyń krwionośnych wyróżnia się co najmniej trzy ważne endogenne gazotransmitery — tlenek azotu (NO), tlenek węgla (CO) oraz najpóźniej opisany — siarkowodór $\left(\mathrm{H}_{2} \mathrm{~S}\right)$. Krótką charakterystykę tych gazotransmiterów przedstawiono w tabeli 1.
Aktualnie wiadomo, że uwolnienie $\mathrm{H}_{2} \mathrm{~S}$ powoduje otwieranie ATP-zależnych kanałów potasowych, co skutkuje między innymi: wazodylatacją, dodatkowym efektem hipotensyjnym, poprawą funkcji śródbłonka, zwiększeniem aktywności endotelialnej syntazy NO, zmniejszeniem uszkodzenia pozawałowego, wspomożeniem zjawiska hartowania przez niedokrwienie (ang. preconditioning), zmniejszeniem metabolizmu komórkowego. Ponadto uwolnienie $\mathrm{H}_{2} \mathrm{~S}$ może się przekładać na efekt antyagregacyjny płytek, zmniejszać odczyn zapalny oraz działać inotropowo dodatnio na mięsień sercowy i kardioprotekcyjnie. Powszechnie dyskutuje się "przeciwstarzeniowe” efekty działania $\mathrm{H}_{2} \mathrm{~S}$ - zmniejszanie niestabilności genomu i zapobieganie skracaniu telomerów, dysfunkcji mitochondrialnej czy zakłóceniom komunikacji międzykomórkowej. W 2015 roku opisano efekt zofenoprilu jako leku zwiększającego biodostępność $\mathrm{H}_{2} \mathrm{~S}$ (Br J Pharmacol. 2015). W 2016 roku z kolei powiązano zwiększanie biodostępności $\mathrm{H}_{2} \mathrm{~S}$ za pomocą zofenoprilu z ograniczeniem uszkodzenia poreperfuzyjnego (J Am Heart Assoc. 2016). Wiadomo, że w badaniach kardiologii eksperymentalnej lek ten wywiera o wiele korzystniejszy efekt niż porównywany z nim — i najczęściej obecnie wybierany inhibitor ACE — ramipril.

\section{BADANIE SMILE-4 - BEZPOŚREDNIE PORÓWNANIE ZOFENOPRILU Z RAMIPRILEM}

Wszystkie omówione wyżej fakty oraz przypuszczenie, że zofenopril może być istotnie lepszym inhibitorem ACE niż ramipril, doprowadziły do zaprojektowania badania SMILE-4. Jego głównym pomysłodawcą był kierownik Kliniki Kardiologii Uniwersytetu Bolońskiego - prof. Claudio Borghi (ryc. 1).

Historia cyklu badań SMILE (zarówno badania SMILE PILOT, badań SMILE, SMILE-2, SMILE-3 ISCHEMIA, jak i badania SMILE-4) została dokładnie opisana w artykule dr. hab. n. med. Filipa M. Szymańskiego. W 2017 roku ukazała się publikacja, w której przedstawiono 5-letni okres obserwacji badania SMILE-4. Artykuł dr. hab. n. med. Filipa M. Szymańskiego kończy rycina z tej publikacji, zatem zacznijmy właśnie od niej. 
Tabela 1. Krótka charakterystyka gazotransmiterów z punktu widzenia aktualnej wiedzy fizjologicznej (tabela autorska — Krzysztof J. Filipiak, 2017)

\begin{tabular}{|lccc|} 
& Tlenek azotu (NO) & Tlenek węgla (CO) & Siarkowodór $\left(\mathbf{H}_{2} \mathbf{S}\right)$ \\
\hline $\begin{array}{l}\text { Rok opisania jako gazotransmitera } \\
\text { w ludzkich tętnicach }\end{array}$ & 1987 & 1991 & 1998 \\
\hline Enzym produkujący & $\begin{array}{l}\text { Endotelialna syntaza } \\
\text { tlenku azotu (eNOS) }\end{array}$ & $\begin{array}{c}\text { Oksygenaza hemowa (HO-1) } \\
\text { Okres półtrwania }\end{array}$ & $\begin{array}{c}\text { Gamma-cystationaza (CSE), } \\
\text { beta-cystationaza (CBS) }\end{array}$ \\
\hline $\begin{array}{l}\text { Mechanizm działania (wtórny } \\
\text { przekaźnik cytofizjologiczny) }\end{array}$ & Cykliczny GMP & Cykliczny GMP & Kekundy \\
\hline Kardioprotekcyjność & Tak potasowy ATP-zależny \\
\hline $\begin{array}{l}\text { Zastosowanie farmakologiczne } \\
\text { (leki zwiększające działanie }\end{array}$ & Statyny & Tak & Tak \\
gazotransmitera) & Inhibitory ACE (wszystkie) & Nieznane & Inhibitory ACE z grupą \\
\end{tabular}

GMP — monofosforan guanozyny; ATP — trifosforan adenozyny; ACE — konwertaza angiotensyny

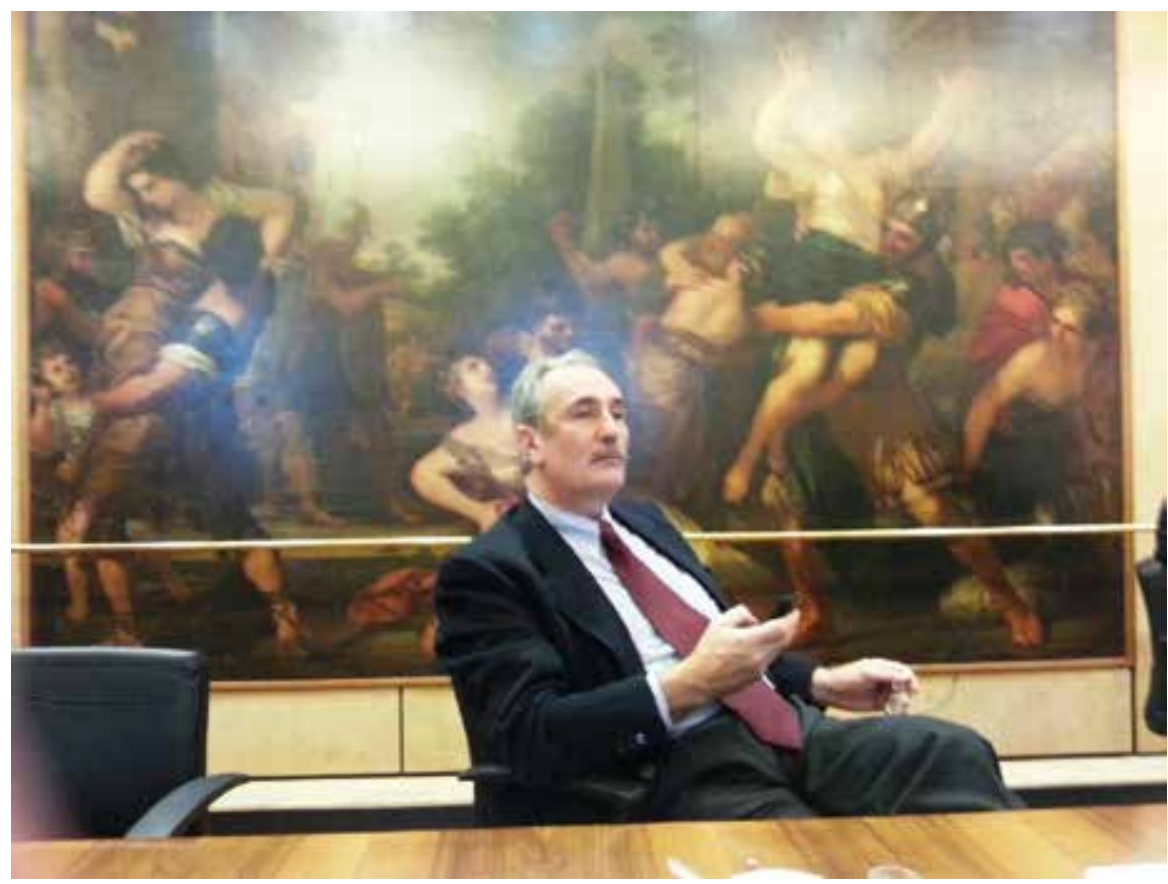

Rycina 1. Profesor Claudio Borghi - projektodawca badań SMILE, w tym badania SMILE-4 (zdjęcie prof. Claudio Borghi wykonane przez prof. Andrzeja Tykarskiego, ówczesnego Prezesa Polskiego Towarzystwa Nadciśnienia Tętniczego we Florencji; dzięki uprzejmości i zgodzie fotografa oraz fotografowanego)

Jak już stwierdzono, oryginalne badanie SMILE-4 było randomizowanym, przeprowadzonym metodą podwójnie ślepej próby, badaniem III fazy. Odległa obserwacja badania SMILE-4 objęła analizę intention-to-treat, a więc zgodnie z pierwotnym losowaniem (ramipril vs. zofenopril — wg intencji leczenia). To takiemu „widzeniu badania” odpowiada rycina z komentowanego artykułu. W rzeczywistości, w obserwacji zakończonego badania, chory może kontynuować przyjmowanie przepisanego mu leku, zamienić go na lek z drugiej grupy badania, przyjmować jeszcze inny lek (ani zofenopril, ani ramipril) albo w ogóle nie stosować leku. Tak działo się również w badaniu SMILE-4 po jego zakończeniu. Przypomnijmy: 


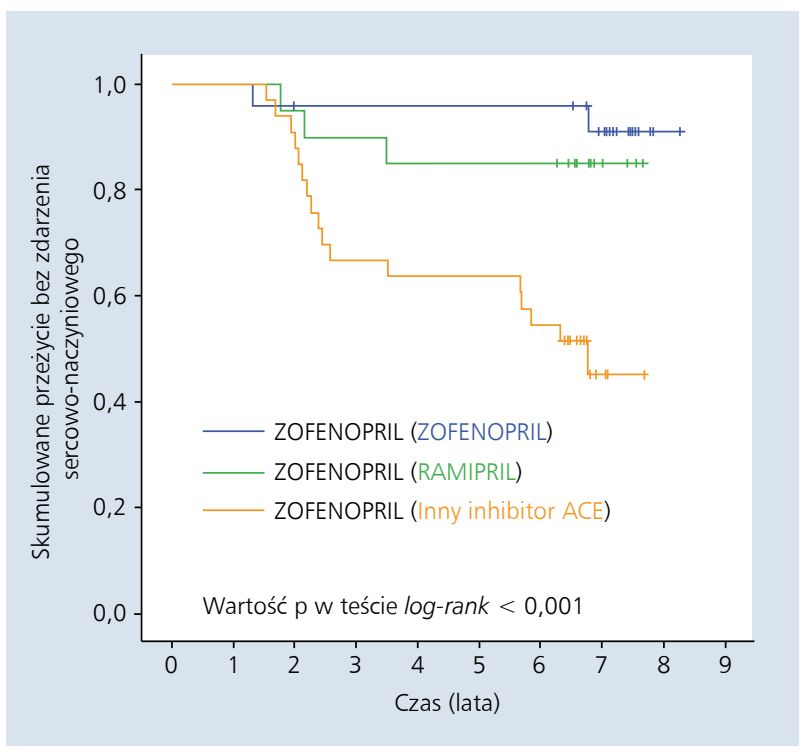

Rycina 2. Obserwacja odległa badania SMILE-4 — dane dotyczące krzywych przeżycia w grupie pierwotnie losowo przydzielonej do przyjmowania zofenoprilu, która w otwartej fazie obserwacji kontynuowała stosowanie tego leku (kolor niebieski), przyjmowała lek przeciwny — ramipril (kolor zielony) lub całkiem inny inhibitor konwertazy angiotensyny (ACE) (kolor pomarańczowy) (dzięki uprzejmości głównego badacza — prof. Claudio Borghi, 2017)

— 28,9\% uczestników leczono zgodnie z pierwotnym zaleceniem (wcześniejszą randomizacją);

- u 34,9\% uczestników leczenie zmieniono na przeciwne (zofenopril na ramipril lub ramipril na zofenopril);

- u 36,2\% podano inny inhibitor ACE niż zofenopril i ramipril.

Aby odpowiedzieć na pytanie, jak dane leczenie wpływało na przeżycie bez incydentu sercowo-naczyniowego w tych trzech grupach, warto byłoby przeanalizować wykresy dotyczące każdej z tych trzech grup pacjentów — zarówno w grupie pierwotnie przydzielonej do przyjmowania zofenoprilu, jak i w grupie pierwotnie przydzielonej do przyjmowania ramiprilu. Dane takie, dzięki uprzejmości prof. Claudio Borghi, zaprezentowano na rycinach 2 i 3.

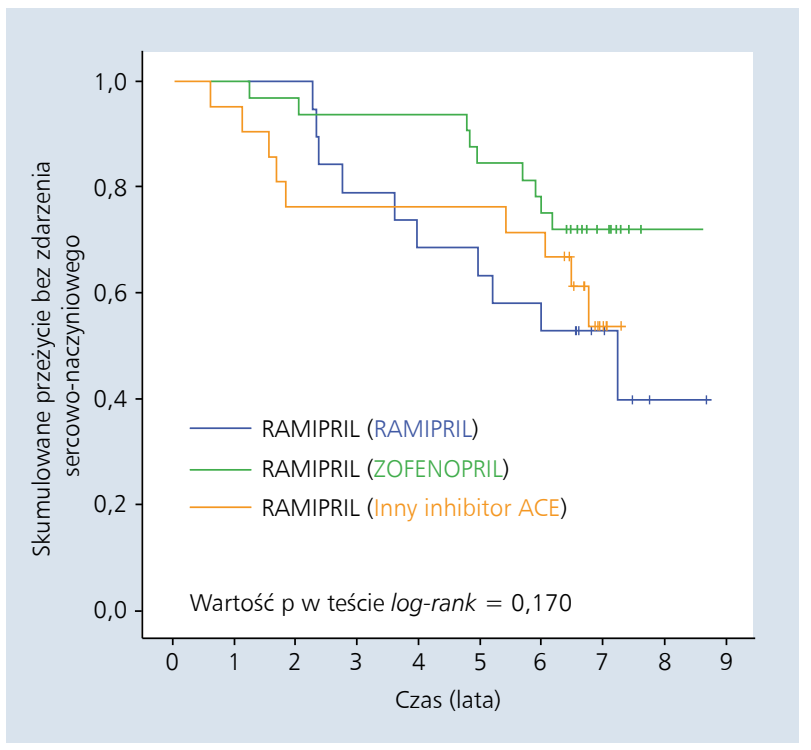

Rycina 3. Obserwacja odległa badania SMILE-4 - dane dotyczące krzywych przeżycia w grupie pierwotnie losowo przydzielonej do przyjmowania ramiprilu, która w otwartej fazie obserwacji kontynuowała stosowanie tego leku (kolor niebieski), przyjmowała lek przeciwny — zofenopril (kolor zielony) lub całkiem inny inhibitor konwertazy angiotensyny (ACE) (kolor pomarańczowy) (dzięki uprzejmości głównego badacza — prof. Claudio Borghi, 2017)

Analiza wykresów z rycin 2 i 3 wskazuje, że odległa obserwacja badania SMILE-4 wskazuje na korzyść zofenoprilu nie tylko w przypadku analizy intention-to-treat według grup randomizacji, ale także według rzeczywistego leczenia. To dodatkowy atut zofenoprilu, którym ten właśnie lek przyciąga naszą uwagę.

Podsumowując, w odległej analizie badania SMILE-4 potwierdzono dodatkowe, plejotropowe działanie zofenoprilu na tle starszych, mniej doskonałych inhibitorów ACE. Może to potwierdzać tezę postawioną w pierwszym zdaniu niniejszego komentarza.

Konflikt interesów: honoraria wykładowe i udział w ciałach doradczych następujących producentów inhibitorów konwertazy angiotensyny: Adamed, Berlin-Chemie, Krka, MSD, Pfizer, Polpharma, Recordati, Sanofi, Servier. 